\title{
Relationship between Paternalistic Leadership and Organizational Commitment in Hospitality Industry: Case of Antalya, Turkey
}

\author{
Nedim Yüzbaşioğlu \\ Akdeniz University, Tourism Faculty \\ Oğuz Doğan
}

Antalya Bilim University, Tourism Faculty

Doi: 10.2478/ajis-2018-0017

\begin{abstract}
The purpose of this study is to examine the relationship between paternalistic leadership and organizational commitment in hotel enterprises. For this purpose, the data obtained from 243 employees at randomly selected hotel enterprises operating in Antalya region. The findings indicated that there is a relationship between paternalistic leadership and organizational commitment. Furthermore, a moderating relationship was found between benevolent leadership and affective commitment, continuance commitment, normative commitment. The findings also indicated that there is a low-level relationship between authoritarian leadership and continuance commitment.
\end{abstract}

Keywords: Paternalistic leadership, Organizational commitment, Hotel enterprises, Antalya

\section{Introduction}

The organizational commitment is one of the main concepts in organizational behavior literature for many years (Özkalp and Kırel, 2013: 664) and it is still important for organizations and managers (Lo et al., 2010:79). Individuals have attitudes towards their organizations or workplaces as well as towards their jobs. This situation is stated as organizational commitment. In other words, organizational commitment is expressed as level of employee's involvement in and their willingness to remain in the organization as part of it (Özkalp and Kırel, 2013: 664-665). Organizational commitmen can be in various forms can affect the organizational effectiveness and employee wellbeing (Meyer and Hersovitch, 2001: 296). Lok and Crawford (2003) state that when employees are dissatisfied at work, they are less committed and will look for other opportunities to quit and if opportunities are unavailable, they may emotionally or mentally "withdraw" from the organization. Lo et al. (2010) claim that the organizational commitment is the one of the key elements of an organization's survival.

Özkalp and Kırel (2013) assert that organizational commitment can reduce employee turnover rates and recruitment costs, they may also encourage the employees to adopt vision of the organization so that, employees can work harder to achieve the goal of the organization. In addition, this also provides the survival of enterprises. It is, therefore, possible to argue that, organizational commitment has a vital role for enterprises to protect and sustain their success and stability. Today's enterprises operate in a more competitive environment than in the past. For this reason, human capital plays a significant role of taking advantage in a competition in order to place itself strategic position in the competitive environment. 
Concept of paternalism dates back to the early works of Max Weber, who conceptualized paternalism as one form of legitimated authority (Pellegrini and Scandura, 2008: 568). However, studies on paternalistic leadership have been drawn attentions of researcher in past two decades. Paternalistic leadership can be defined as a leadership style that combines authority and strong discipline with a fatherly benevolence (Kurt, 2013: 324). Paternalistic leaders act like a parent towards their employees, assuming the role of "father" who knows better than everyone. Paternalistic leaders are also interacting with their employees in their professional lives as well as, their private lives. So, they support them in every sense and in return, they expect employees to obey himself in the hierarchy of the organization (Öner, 2012: 302).

Hakimian et al. (2014) argue that the leadership styles have play an important role on organizational commitment. The previous studies showed that the effects of leadership styles on employees' behaviors (performance, commitment, organizational citizenship etc.) differ in accordance with the cultural structure of society in which the enterprise operates. The findings of these studies indicated that the leadership styles in Asia, the Middle East and European countries differ due to the differences in the social structures of the countries (Aycan et al., 2001; Pellegrini and Scandura, 2006, 2008 etc.). For instance, in Asia and the Middle East countries, paternalistic leadership is more prevalent because of their collectivist structure of the society. As a result of this assumption it possible to argue that the leadership behaviors in Turkey mostly reflect the paternalistic leadership style due to collectivist structure of the society.

The studies in the literature that examine the relationship between paternalistic leadership and organizational commitment have been drawing the attentions of researcher as well as practitioner (see, Cheng et al., 2002; Fahr et al., 2004; Pellegrini et al., 2007; Erben and Güneşer, 2008; Rehman and Afsar, 2012; Renderee and Chaudhry, 2012; Saher et al., 2013; Afsar, 2014), however, the literature presents limited number of studies regarding the relationship of paternalistic leadership with organizational commitment in hospitality industry in Turkey (see Arsezen et al., 2015). Objective of this study is, therefore, to examine the relationship between paternalistic leadership and organizational commitment in tourism enterprises. In accordance with its objective a survey was conducted with the employees of the hotel enterprises operating in Antalya. When the main purpose of the research is considered, the following questions are addressed:

- Is there a positive relationship between benevolent leadership and affective commitment, continuance commitment, normative commitment?

- Is there a positive relationship between moral leadership and affective commitment, continuance commitment, normative commitment?

- Is there a positive relationship between authoritarian leadership and affective commitment, continuance commitment, normative commitment?

The results of this study are, therefore, expected to make contribute to filling the gap in the literature.

\section{Literature Review}

\subsection{Paternalistic Leadership}

Paternalism is defined as hierarchical relationships in which the leader guides his subordinates like a parent in their private and professional lifes and in change expects the respect and the loyalty (Gelfand et al., 2007: 493; Pellegrini et al., 2010: 394). Paternalistic leadership refers to a leadership style that emerges from the combination of fatherly benevolence and moral integrity with solid discipline and authority (Chen et al., 2014:799; Chou et al., 2015:4). Although there is no common consensus (Afsar, 2014: 794; Cheng vd., 2014: 84), the paternalistic leadership is composed of three dimensions, namely, authoritarianism, benevolence and morality (Fahr and Cheng, 2000: 94; Pellegrini and Scandura, 2008: 567).

Authoritarianism means to leadership behaviors that require an absolute authority and unquestioning obedience (Pellegrini and Scandura, 2008: 567; Wu and Chan, 2012: 633). Authoritarian leadership includes acts such as subjugating with power, addressing authority and control and ensuring the adoption of a particular doctrine (Chen and Kao, 2009: 2534). The 
authoritarian leader keeps his authority under his control and asks his subordinates to fulfill all his requests without any question (Hayek et al., 2010: 371). Authoritarian leader tries to maintain his authority by setting rules, determining responsibilities, punishment and rewards (Cheng vd., 2014:83). Benevolence refers to leadership behaviors that concern for employees' and their families' well-being (Irawanto et al., 2013: 4). Benevolent leaders are compassionate and tolerant to their employees and pay close attention to them both their professional and private life (Chen and Kao, 2009: 2534) and in change they expect to be grateful to him and to fulfill his obligations from the employees (Cheng et al., 2004: 91). Moral leadership can be describes as having superior personal virtues, high degree of self-discipline and unselfishness (Irawanto et al., 2013:4). Moral leaders demonstrate behaviors in their personal and professional life that will affect their employees and allow leaders to be respected (Afsar, 2014: 794; Chen et al., 2014:799). Moral leader does not use the personal relations or perform inaccurate practices to achieve personal interests (Chan, 2014:668). Therefore, moral leaders act as a role model to employees. Mortality role model is one of the important element of paternalistic leadership. Leaders expect their employees to adhere their moral integrity, to believe in their benevolence and to obey their authority by acting in high ethical standards (Cheng et al., 2014:83).

Farh and Cheng (2000) state that paternalistic leadership dimensions affect the employees' effectiveness. Niu et al. (2009) argue that high benevolence strengths the positive relationship between authorism and subordinates' activities and that the moral virtues of leader will enhance the influence of the leader' authoritarian and benevolence characteristics on the employees' effectiveness. Cheng et al. (2004) claim that if the leader has a sense of high benevolence, authoritarianism has either positive effect or no effects but if the leader has a sense of low benevolence, authoritarianism has negative effects on employees' behaviors.

Paternalism is a very effective leadership style for countries with collectivist society (Pellegrini and Scandura, 2008: 570; Pellegrini et al., 2010: 395). In fact, it is desired and expected situation in collective societies that the paternalistic leader is involved in the employee's personal life. However, in individualistic societies, paternalism is perceived as privacy violation (Pellegrini and Scandura, 2008: 570), "benevolent dictatorship" (Northouse, 1997: 39; Pellegrini and Scandura, 2008: 570), "an insidious form of discrimination" (Colella et al., 2005: 26) and "iron fist in velvet hand" (Erben and Ötken, 2014: 106). In developed countries, paternalistic leadership is seeming equivalent to authoritarianism (Pellegrini and Scandura, 2008: 570) and authoritarian leadership is thought to be an inefficient leadership style. For this reason, they have a negative view of it (Irawanto et al., 2013: 4). Hence, Öner (2012) states that the paternalistic leadership is prevalent leadership style in developing countries. For instance, in Asia, the Middle East and Latina America, paternalism is more prevalent (Pellegrini and Scandura, 2008: 568; Pellegrini et al., 2010:3 94). According to the results of a study conducted by Aycan et al. (2006) in 10 countries, India, Turkey, China and Pakistan have the highest paternalism score whereas, Russia, Romania, USA and Canada have middle level and Israel and Germany have the lowest paternalism score.

\subsection{Organizational Commitment}

The term "commitment" can be defined as the strength of an employee's identification with and involvement in a particular organization. Organizational commitment can be defined in various ways (Saher et al., 2013: 444). Allen and Meyer (1990) described organizational commitment as psychological conditions that bind an employee to the organization (Ortiz, 2010) and they discussed the organizational commitment in three dimensions: affective commitment, continuance commitment and normative commitment (Randeree and Chaudry, 2012: 65).

Affective commitment refers to create an emotional bond to an organization (Cole and Johnson, 2007: 193). Affective commitment is characterized by employees' personal desires to remain with the organization (Hakimian et al., 2014: 374). Thus, employees with strong affective commitment remain with the organization because they want to do so (Allen and Meyer, 1996: 253). Some researchers revealed that there is a positive relationship between organizational commitment and employee' behaviors. Accordingly, they found the positive relationship between organizational commitment and performance (Muse and Stamper, 2007), job satisfaction 
(Vandenberg and Lance, 1992; Russ and McNeilly, 1995; Cetin, 2006) and organizational justice (Meyer et al, 2002).

Continuance commitment means to an awareness of the costs associated with leaving the organization (Erben and Güneşer, 2007: 960). In other words, the employee does not want to leave the job, taking into consideration possible losses that may occur when leaves the organization (Özkalp and Kırel, 2013: 667). Continuance commitment may decrease turnover rates and recruitment costs but it has no effects on employees' performance (Hakimian et al., 2014: 374). Hakimian et al. (2014) suggest that employees who do not leave the organization due to the potential risks, can develop feelings of frustration and resentment. Therefore, Meyer and Allen (1997) claim that employees with strong continuance commitment can negative impact on organizational development.

Normative commitment is a moral dimension of organizational commitment (Randeree and Chaudry, 2012: 65). It refers to employees' sense of responsibilities and liabilities towards an organization (Cole and Johnson, 2007: 193; Randeree and Chaudrhy, 2012: 65). In this type of commitment, an employee feels obligated to the organization because of investments and expenditure (personal development, technical trainings etc.) made by the organization for the employees. This leads the employees to remain in organization and bids them normatively to the organization (Özkan and Kırel, 2013: 667). Normative commitment has also an important influence on successful fulfillment of the duties. However, compared with the affective commitment, the employees with normative commitment may not display the same enthusiasm or attachment (Hakimian vd., 2014:374). Cetin (2006) state that there is a positive relationship between normative commitment and work attendance, job performance, organizational citizenship and job satisfaction. As is seen, all dimensions of commitment have noticiable implications for remaining with or leaving an organization (Allen and Meyer, 1996: 253).

\subsection{Paternalistic Leadership and Commitment}

Paternalistic leadership has strong impacts on organizational commitment (Rehman and Afsar, 2012; Sahr et al., 2013). Previous studies which examine the relationship between paternalistic leadership and organizational commitment indicated that there is positive relationship between organizational commitment and benevolence leadership and mortality leadership, but negative relationship between authoritarian leadership and organizational commitment. Some studies found positive relationship between organizational commitment and benevolence leadership (Cheng et al., 2002; Fahr et al., 2004), mortality leadership (Fahr et al., 2004) and negative relationship between organizational commitment and authoritarian leadership (Cheng et al., 2002). Erben and Güneşer (2008) revealed that benevolence leadership has moderate impact on affective commitment and has strong impact on continuance commitment. Afsar (2014) showed that mortality leadership has positive impact on affective commitment and continuance commitment whereas, authoritarian leadership has negative impact on affective commitment.

With above discussions, the hypothesises of the study are below:

$H_{1}$ : There is a positive relationship between benevolent leadership and affective commitment.

$H_{1 a}$ : There is a positive relationship between benevolent leadership and continuance commitment.

$H_{1 b}$ : There is a positive relationship between benevolent leadership and normative commitment.

$\mathrm{H}_{2}$ : There is a positive relationship between moral leadership and affective commitment.

$H_{2 a}$ : There is a positive relationship between moral leadership and continuance commitment.

$H_{2 b}$ : There is a positive relationship between moral leadership and normative commitment.

$\mathrm{H}_{3}$ : There is a positive relationship between authoritarian leadership and affective commitment.

$H_{3 a}$ : There is a positive relationship between authoritarian leadership and continuance commitment.

$H_{3 b}$ : There is a positive relationship between authoritarian leadership and normative commitment. 


\section{Methodology}

\subsection{Sample and Procedures}

G-Power analysis was used in order to determine the sample size. As a G-Power analysis, it was determined that the sample size should be at least 238 persons at he $95 \%$ confidence bound and $90 \%$ power. Therefore, from Februaray 2016 to November 2016, the study conducted with randomly selected hotel enterprises operating in Antalya. The drop off/ pick-up survey method was used. In this survery method, an interviewer delivers and picks up the questionnaire, explains the study and general instructions, motivates the respondent to participate and sets a date for picking up the questionnaire (Mangione et al., 1982: 337). In this contex, the purposes of the study were explained to each department managers of the hotel enterprises and than the questionnaires were dropped off to managers who agreed to participate. After two weeks later, the questionnaires were picked-up. Thus, the data obtained from 243 employees.

Table 1. Power Analysis

\begin{tabular}{|l|l|c|}
\hline \multirow{4}{*}{ Input Parameters } & Effect Size & 0.30 \\
\cline { 2 - 3 } & $\alpha$. Error Problem & 0.05 \\
\cline { 2 - 3 } & Power (1- $\beta$ error problem) & 0.90 \\
\cline { 2 - 3 } & Df & 1 \\
\hline \multirow{4}{*}{ Output Parameters } & Noncentrality Parameter & 21.4200000 \\
\cline { 2 - 3 } & Critical X & 1.8716706 \\
\cline { 2 - 3 } & Total Sample Size & $\mathbf{2 3 8}$ \\
\cline { 2 - 3 } & Actual Power & 0.9011561 \\
\hline
\end{tabular}

\subsection{The Questionnaire}

The questionnaire consisted of three parts. The first one included the paternalistic leadership questionnaire and the second one included the organizational commitment questionnaire. Paternalistic leadership was measured by the paternalistic leadership (PL) scale which consists of 26 items developed by Cheng et al. (2004). PL scale has three dimensions: authoritarian leadership, benevolent leadership and moral leadership. Organizational commitment was measured by the commitment questionnaire (OCQ) which consists of 18 items developed by Allen and Meyer (1990). The scale has three dimensions: affective commitment, continuance commitment and normative commitment. All the items in the scales were desingned in a 5 Likert response scale ranging from 1: strongly disagree to 5: strongly agree. The scales were translated from English into Turkish and the retranslated into English to assure accuracy of meaning. The last one included demographic questions related to respondents' gender, age group, marital status, work experience and education level.

\section{Findings}

The Table 1 provides the demographic profile of respondets. Regarding gender, $69.5 \%$ of respondents were male and $30.5 \%$ were female. Regarding age, $57.6 \%$ of respondents were ranged from 20 to 29 age group. Regarding marital status, $63.8 \%$ of respondents were bachelor and $36.2 \%$ were married. Regarding work experience, $44.9 \%$ of respondents had worked for $1-3$ years and $21.8 \%$ had worked for $4-6$ years. Regarding education level, $37.4 \%$ of respondents had a high school degree, $28.4 \%$ had an undergraduate degree and $23 \%$ had an associate degree. 
Table 2. Demographic Profile of Respondents

\begin{tabular}{|c|c|c|c|c|c|c|c|}
\hline & & $f$ & $\%$ & & & $f$ & $\%$ \\
\hline \multirow{3}{*}{ Gender } & Male & 169 & 69.5 & \multirow{6}{*}{ Work Experience } & Under 1 year & 48 & 19.8 \\
\hline & Female & 74 & 30.5 & & $1-3$ & 109 & 44.9 \\
\hline & Total & 243 & 100 & & $4-6$ & 53 & 21.8 \\
\hline \multirow{6}{*}{ Age Group } & Under 20 & 12 & 4.9 & & $7-9$ & 20 & 8.2 \\
\hline & $20-29$ & 140 & 57.6 & & 10 years and above & 13 & 5.3 \\
\hline & $30-39$ & 70 & 28.8 & & Total & 243 & 100 \\
\hline & $40-49$ & 19 & 7.8 & \multirow{6}{*}{ Education Level } & Elementary & 18 & 7.4 \\
\hline & 50 and above & 2 & 0.8 & & High School & 91 & 37.4 \\
\hline & Total & 243 & 100 & & Associate & 56 & 23.0 \\
\hline \multirow{3}{*}{ Marital Status } & Married & 88 & 36.2 & & Undergraduate & 69 & 28.4 \\
\hline & Bachelor & 155 & 63.8 & & Graduate & 9 & 3.7 \\
\hline & Total & 243 & 100 & & Total & 243 & 100 \\
\hline
\end{tabular}

Factor analysis was conducted in order to find the factor structure of paternalistic leadership scale. Before the factor analysis was conducted, a Kaiser-Meyer-Olkin measure of sampling adequacy was calculated as 0.857 which is above the accepted value. The Bartlett's test showed that the variables suitable for the factor analysis $(p=0.000$, Chi-Square: 2352.850$)$. Other criterias for factor analysis were that factors with eigenvalues must be higher than 1.00 and factor loading must be higher than 0.50 (Hair et al. 1998: 113) and any item with loading to more than one factor was excluded from the analysis. The 26 items were factor analyzed with using principal components solution with varimax rotation. Some of the items that had cross-loading were excluded from analysis. Therefore, three factors (benevolent leadership, moral leadership, authoritarian leadership) were obtained and these factors were explaining $55.700 \%$ of total variance which was above the acceptable value (Nakip, 2003: 412). The Cronbach's Alpha values of the factors ranged from 0.668 to 0.915 which showed good internal reliability for each factors (Hair et al., 1998: 118). However, the result of factor analysis differed from Cheng et al.'s (2004) study. Two items (My supervisor asks me to obey his/her instructions completely, my supervisor always behaves in a commanding fashion in front of employees) in the authoritarian leadership dimension on original scale took place in the moral leadership dimension and one item (My supervisor never avenges a personal wrong in the name of public interest when he/she is offended) in the moral leadership dimension took place in the benevolent leadership dimension. Besides, three items (My supervisor determined all decisions in the organization whether they are important or not; my supervisor always has the last say in the meeting; my supervisor emphasizes that our group must have the best performance of all the units in the organization) with the factor loading less than 0.50 were excluded from the analysis. Table 3 provides the result of the factor analysis.

Table 3. The Factor Analysis Results of PL

\begin{tabular}{|c|c|c|c|}
\hline Factors & $\begin{array}{c}\text { Factor } \\
\text { Loadings }\end{array}$ & $\begin{array}{c}\text { Variance } \\
\%\end{array}$ & $\begin{array}{c}\text { Cronbach } \\
\text { Alpha }\end{array}$ \\
\hline Factor 1: Benevolent Leadership & & 28.559 & 0.915 \\
\hline My supervisor is like a family member when he/she gets along with us. & 0.686 & & \\
\hline My supervisor devotes all his/her energy to taking care of me. & 0.747 & & \\
\hline Beyond work relations, my supervisor expresses concern about my daily life & 0.792 & & \\
\hline My supervisor ordinarily shows a kind concern for my comfort & 0.782 & & \\
\hline My supervisor will help me when I'm in an emergency & 0.688 & & \\
\hline My supervisor meets my needs according to my personal requests & 0.712 & & \\
\hline My supervisor encourages me when I encounter arduous problems & 0.678 & & \\
\hline My supervisor takes good care of my family members as well & 0.789 & & \\
\hline My supervisor tries to understand what the cause is when I don't perform well & 0.666 & & \\
\hline My supervisor handles what is difficult to do or manage in everyday life for me & 0.719 & & \\
\hline $\begin{array}{l}\text { My supervisor never avenges a personal wrong in the name of public interest when he/she } \\
\text { is offended. (reversed) }\end{array}$ & 0.562 & & \\
\hline
\end{tabular}




\begin{tabular}{lll}
\hline Factor 2: Moral Leadership & 15.263 & 0.787 \\
\hline My supervisor employs people according to their virtues and does not envy others' abilities & 0.524 \\
and virtues & \\
My supervisor doesn't take the credit for my achievements and ontributions for & 0.723 \\
himself/herself. & 0.714 \\
My supervisor does not take advantage of me for personal gain & 0.744 \\
My supervisor does not use guanxi (personal relationships) or back-door practices to obtain & 0.737 \\
illicit personal gains & 0.546 & 11.879 \\
My supervisor asks me to obey his/her instructions completely & 0.668 \\
My supervisor always behaves in a commanding fashion in front of employees & 0.730 \\
\hline Factor 3: Authoritarian Leadership & 0.756 \\
\hline Ifeel pressured when working with him/her & 0.783 \\
My supervisor exercises strict discipline over subordinates & 0.748 \\
My supervisor scolds us when we can't accomplish our tasks. & \\
We have to follow his/her rules to get things done. If not, he/she punishes us severely. & \\
\hline Total variance $\%): 55.700$ KMO: 0.894 & \\
Bartlett significance value: $2352.850 \quad$ p: 0.000 &
\end{tabular}

Factor analysis was also conducted in order to find the factor structure of OCQ items. KaiserMeyer-Olkin measure of sampling adequacy was calculated as 0.804 which is above the accepted value. The Bartlett's test showed that the variables suitable for the factor analysis $(p=0.000$, ChiSquare: 1067.698). The 20 items were factor analyzed with using principal components solution with varimax rotation. Some of the items that had low factor loading than 0.50 (I do not feel a strong sense of belonging to my organization; I feel that I have too few options to consider leaving this organization; One of the major reasons I continue to work for this organization is that leaving would require considerable personal sacrifice -another organization may not match the overall benefits I have here; Right now, staying with my organization is a matter of necessity as much as desire) were excluded from analysis. Therefore, three factors (affective commitment, continuance commitment, normative commitment) were obtained and these factors were explaining $52.773 \%$ of total variance which was above the acceptable value (Nakip, 2003: 412). The Cronbach's Alpha values of the factors ranged from 0.705 to 0.880 which showed good internal reliability for each factors (Hair et al., 1998: 118).

Table 4. The Factor Analysis Results of OCQ

\begin{tabular}{|c|c|c|c|}
\hline Factors & $\begin{array}{l}\text { Factor } \\
\text { Loadings }\end{array}$ & $\begin{array}{l}\text { Variance } \\
\%\end{array}$ & $\begin{array}{l}\text { Cronbach } \\
\text { Alpha }\end{array}$ \\
\hline Factor 1: Affective Commitment & & 28.223 & 0.880 \\
\hline I would be very happy to spend the rest of my career with this organization & .730 & & \\
\hline I really feel as if this organization's problems are my own. & .654 & & \\
\hline I do not feel like 'part of the family' at my organization (R) & .517 & & \\
\hline I do not feel 'emotionally attached' to this organization (R) & .536 & & \\
\hline This organization has a great deal of personal meaning for me & .667 & & \\
\hline Factor 2: Continuance Commitment & & 12.380 & 0.775 \\
\hline $\begin{array}{l}\text { Too much in my life would be disrupted if I decided I wanted to leave my organization now. } \\
\text { I feel that I have too few options to consider leaving this organization. }\end{array}$ & $\begin{array}{l}.567 \\
.772\end{array}$ & & \\
\hline $\begin{array}{l}\text { One of the few serious consequences of leaving this organization would be the scarcity of } \\
\text { available alternatives. }\end{array}$ & .791 & & \\
\hline I am not afraid of what might happen if I quit my job without having another one lined up. (R) & .615 & & \\
\hline Factor 3: Normative Commitment & & 12.170 & 0.705 \\
\hline I do not feel any obligation to remain with my current employer (R) & .717 & & \\
\hline Even if it were to my advantage, I do not feel it would be right to leave my organization now & .561 & & \\
\hline I would feel guilty if I left my organization now & .695 & & \\
\hline This organization deserves my loyalty & .791 & & \\
\hline $\begin{array}{l}\text { I would not leave my organization right now because I have a sense of obligation to the } \\
\text { people in it }\end{array}$ & .637 & & \\
\hline I owe a great deal to my organization & .673 & & \\
\hline $\begin{array}{l}\text { Total variance }(\%): 52.773 \mathrm{KMO}: 0.804 \\
\text { Bartlett significance value: } 1067.698 \mathrm{p}: 0.000\end{array}$ & & & \\
\hline
\end{tabular}

Pearson Correlation analysis was used in order to test the hypothesis. Table 5 provides the results of correlation analysis. Büyüköztürk (2012) states that if the correlation coefficient is between 0.00 - 
0.30 , there is low level; between $0.30-0.70$, there is moderate level; between $0.70-1.00$, there is high level relation. Thus, there is a moderate relationship between benevolent leadership and affective commitment ( $r: 0.325, p: 0.000)$, continuance commitment ( $r: 0.346, p: 0.000)$, normative commitment ( $r: 0.434, p: 0.000$ ); between moral leadership and normative commitment (r: 0.387, p: $0.000)$. there is a low level relationship between moral leadership and affective commitment $(r$ : 0.275 , p: 0.000), continuance commitment ( $\mathrm{r}: 0.150$, p: 0.020); between authoritarian leadership and continuance commitment ( $r: 0.175, p: 0.006)$. Regarding the correlation analysis results, the hypothesises were supported, except $H_{3}$ and $H_{3 b}$.

Table 5. Correlations Analysis Results

\begin{tabular}{|c|c|c|c|c|c|c|c|}
\hline & & $\begin{array}{l}\text { Benevolent } \\
\text { Leadership }\end{array}$ & $\begin{array}{c}\text { Moral } \\
\text { Leadership }\end{array}$ & $\begin{array}{c}\text { Authoritarian } \\
\text { Leadership }\end{array}$ & $\begin{array}{c}\text { Affective } \\
\text { Commitment }\end{array}$ & $\begin{array}{l}\text { Continuance } \\
\text { Commitment }\end{array}$ & $\begin{array}{l}\text { Normative } \\
\text { Leaderhip }\end{array}$ \\
\hline $\begin{array}{l}\text { Benevolent } \\
\text { Leadership }\end{array}$ & $r$ & 1 & & & & & \\
\hline $\begin{array}{l}\text { Moral } \\
\text { Leadership }\end{array}$ & $r$ & $0.524^{\star *}$ & 1 & & & & \\
\hline $\begin{array}{l}\text { Authoritarian } \\
\text { Leadership }\end{array}$ & $r$ & -0.040 & -0.060 & 1 & & & \\
\hline $\begin{array}{l}\text { Affective } \\
\text { Commitment }\end{array}$ & $r$ & $0.325^{\star *}$ & $0.275^{\star *}$ & 0.083 & 1 & & \\
\hline $\begin{array}{l}\text { Continuance } \\
\text { Commitment }\end{array}$ & $r$ & $0.346^{* *}$ & $0.150^{*}$ & $0.175^{\star *}$ & $0.422^{* *}$ & 1 & \\
\hline $\begin{array}{l}\text { Normative } \\
\text { Commitment }\end{array}$ & $r$ & $0.434^{\star *}$ & $0.387^{* *}$ & 0.057 & $0.527^{\star *}$ & $0.440^{* *}$ & 1 \\
\hline
\end{tabular}

${ }^{*} p<0.05^{* \star} p<0.01$

\section{Results and Discussion}

The tourism industry is labour-intensive. Therefore, it can be said that human capital is an important competitive element for the enterprises operating in the tourism industry. The enterprises invest in human capital in order to increase the service qualities and to take an advantage over competitors. determining the appropriate personnel for the work to be done, the training the personnel etc. are a cost factors for the enterprises. This is why enterprises do not lose the skilled personnel they have. The commitment of employees to the organization is an important influence on the success of enterpireses. For this reason, enterprises are making a number of practices (wage increase, improvement in working conditions, etc.) in order to increase their employees' commitment. Beside these practices, the leadership style that the supervisor has is also an important influence on employees' commitment. In this respect, the main purpose of this study is to examine the relationship between paternalistic leadership and organizational commitment in the tourism industry. For this purpose, a survey was conducted with 243 employees of randomly selected hotel enterprises operating in Antalya.

This study indicates that there are various levels of relationship between paternalistic leadership and organizational commitment. On the otherhand, there are moderate level relationship between benevolent leadership and affective commitment, continuance commitment and normative commitment. Findings of the result supported to smilar studies carried out in different industries (Cheng et al., 2002; Fahr et al., 2006; Pellegrini et al., 2007; Erben and Güneşer, 2008; Rehman and Afsar, 2012) suggest that there is a moderate relationship between benevolent leadership and affective commitment. Erben and Güneşer (20089 and Rehman and Afsar (2012) found a strong relationship between benevolent leadership and continuance commitment. In short, it can be said that regardless of industrial differences, benevolent leadership has a significant effect on organizational commitment. It is also found a moderate relationship between moral leadership and normative commitment whereas low level relationship between moral leadership and affective commitment, continuance commitment. Previous studies (Fahr et al., 2004; Pellegrini et al., 2007; Rehman and Afsar, 2012) indicated that moral leadership improves commitment of the employees. 
The most important finding of the study is that low level relationship between authoritarian leadership and continuance commitment. In other words, those managers who have authoritarian leadership behaviors positively affect the continuance commitment of employees at a low level. The findings differ from the results of previous studies. For instance, Cheng et al. (2002) and Afsar (2014) revealed that manager's authoritarian leadership behaviors negatively affect the organizational commitment of employees. But Aycan et al. (2006) showed that Turkey has a high paternalism score. The reason for this difference may be that of the distinctive characteristic of the society in which the individuals grown up or the cultural structure of the organizations which have been sustain their operations.

It has been known that human capital is playing an important role in getting competitive advantage over its rivals in the tourism industry due to its distinctive charactersitic of being labourintensive. The enterprises, therefore, makes investment in human capital in order to increase the service qualities and to take an advantage over competitors. Determining the appropriate personnel for the work to be done, the training the personnel etc. are counted as cost factors for the enterprises. The reason why enterprises in tourism sectors do not like to lose the skilled personnel they have. On the other hand, the commitment of employees to the organization is an important inluencing factor on the survival of enterpireses. For this reason, enterprises are making many practices (wage increase, improvement in working conditions, etc.) in order to increase their employees' commitment. Beside these practices, the leadership style of supervisor is also a crucial factor that makes an influence on commitment of employees.

This study shed light on the relationship between paternalistic leadership and organizational commitment in hotel enterprises operating in Antalya. Researchers who are keen to follow the field can reach more detailed data on paternalistic leadership and organizational commitment through through qualitative research with deep interviews with employees and managers of hotel enterprises. Moreover, the reasons for the low level positive relationship between authoritarian leadership and organizational commitment can be explored. And also, a similar study can be carried out in other enterprises operating in the tourism industry to examine the relationship between paternalist leadership and organizational commitment.

\section{References}

Afsar, B. (2014). Moral or Authoritative Leadership: Which One is Better for Faculty Members? American Journal of Educational Research, 2(9), 793-800.

Allen, N. J., \& Meyer, J.P. (1990). The measurement and antecedents of affective, continuance and normative commitment to the organization. Journal of Occupational Psychology, 63, 1-18.

Arsezen-Otamis, P., Arikan-Saltik, I., \& Babacan, S. (2015). The Relationship Between Paternalistic Leadership and Business Performance in Small Tourism Businesses: The Moderating Role of Affective Organizational Commitment. Procedia-Social and Behavioral Sciences, 207, 90-97.

Aycan, Z. (2006). Paternalism: Towards conceptual refinement and operationalization. U. Kim, K. Yang ve KK Flwang, (Ed.), Indigenous and cultural psychology: Understanding people in context içinde (445A66).

Büyüköztürk, Ş. (2012). Sosyal bilimler için veri analiz el kitabı (16. Baskı). Ankara: Pegem Akademi Yayıncılık.

Cetin, M. O. (2006). The relationship between job satisfaction, occupational and organizational commitment of academics. Journal of American Academy of Business, 8(1), 78-88.

Chen, X. P., Eberly, M. B., Chiang, T. J., Farh, J. L., \& Cheng, B. S. (2014). Affective trust in Chinese leaders linking paternalistic leadership to employee performance. Journal of Management, 40(3), 796-819.

Chen, X. P., Eberly, M. B., Chiang, T. J., Farh, J. L., \& Cheng, B. S. (2014). Affective trust in Chinese leaders linking paternalistic leadership to employee performance. Journal of Management, 40(3), 796-819.

Cheng, B. S., Chou, L. F., Wu, T. Y., Huang, M. P., \& Farh, J. L. (2004). Paternalistic leadership and subordinate responses: Establishing a leadership model in Chinese organizations. Asian Journal of Social Psychology, 7, 89-117.

Cheng, B.S., Huang, M.P., \& Chou, L.F. (2002). Paternalistic leadership and its effectiveness: Evidence from Chinese organizational teams. Journal of Psychology in Chinese Societies, 3(1): 85-112.

Cheng, B. S., Boer, D., Chou, L. F., Huang, M. P., Yoneyama, S., Shim, D., ... \& Tsai, C. Y. (2014). Paternalistic leadership in four East Asian societies: Generalizability and cultural differences of the triad model. Journal of Cross-Cultural Psychology, 45(1), 82-90.

Chou, W.J., Sibley, C.G., Liu, J.H., Lin, T.T. \& Cheng, B.S. (2015). Pateranlisti leadership profiles: a personcentered approach. Group \& Organization Management, 1-26. 
Cole, P. M., \& Johnson, K. (2007). An exploration of successful copreneurial relationships postdivorce. Family Business Review, 20(3), 185-198.

Durmuş, B., Yurtkoru, E., ve Çinko, M. (2011). Sosyal bilimlerde SPSS'le veri analizi. İstanbul: Beta Basım Yayım Dağıtım A.Ş.

Erben, G. S., \& Güneşer, A. B. (2008). The relationship between paternalistic leadership and organizational commitment: Investigating the role of climate regarding ethics. Journal of Business Ethics, 82(4), 955-968.

Erben, G. S., \& Ökten, A. B. (2014). Paternalist liderlik ve işe ilişkin iyilik ilişkisinde iş-yaşam dengesinin rolü. Yönetim ve Ekonomi Araştırmaları Dergisi, 22, 103-121.

Farh, J. L., Cheng, B., Chou, L. F., \& Chu, X. (2004). Authority and Benevolence: Employee's Responses to Paternalistic Leadership in China. In Academy of Management Annual Meeting, August 6-11, New Orleans.

Farh, J. L., \& Cheng, B. S. (2000). A cultural analysis of paternalistic leadership in Chinese organizations. In Management and organizations in the Chinese context (pp. 84-127). Palgrave Macmillan UK.

Gelfand, M. J., Erez, M., \& Aycan, Z. (2007). Cross-cultural organizational behavior. Annu. Rev. Psychol., 58, 479-514.

Hair, J. F., Black, W. C., Babin, B. J., Anderson, R. E., \& Tatham, R. L. (1998). Multivariate data analysis. Upper Saddle River, NJ: Prentice hall.

Hakimian, F., Farid, H., Ismail, M. N., \& Ismail, I. A. (2014). Paternalistic Leadership and Organizational Commitment. International Journal of Management Excellence, 3(1), 373-378.

Hayek, M., Novicevic, M. M., Humphreys, J. H., \& Jones, N. (2010). Ending the denial of slavery in management history: Paternalistic leadership of Joseph Emory Davis. Journal of Management History, 16(3), 367-379.

Irawanto, D. W., Ramsey, P. L., \& Tweed, D. M. (2013). The Paternalistic Relationship: Authenticity and credibility as a source of healthy relationships. The Journal of Values-Based Leadership, 6(1), 1-11.

Kurt, I. (2013). Paternalist liderlik ile çalışanların işlerine yaratıcı katıım algıları arasındaki ilişkiyi araştırmaya yönelik bir çalışma. Sosyal ve Beşeri Bilimler Dergisi, 5(1), 321-330.

Lo, M. C., Ramayah, T., Min, H. W., \& Songan, P. (2010). The relationship between leadership styles and organizational commitment in Malaysia: role of leader-member exchange. Asia Pacific business review, 16(1-2), 79-103.

Meyer J and Allen N (1997), "Commitment in the Workplace: Theory, Research, and Application", Sage Publications.

Meyer, J. P., Stanley, D. J., Herscovitch, L., \& Topolnytsky, L. (2002). Affective, continuance, and normative commitment to the organization: A meta-analysis of antecedents, correlates, and consequences. Journal of vocational behavior, 61(1), 20-52.

Muse, L. A., \& Stamper, C. L. (2007). Perceived organizational support: Evidence for a mediated association with work performance. Journal of Managerial Issues, 517-535.

Nakip, M. (2003). Pazarlama araştırmaları teknikler ve uygulamalar. Ankara: Seçkin Yayıncılık.

Niu, C. P., Wang, A. C., \& Cheng, B. S. (2009). Effectiveness of a moral and benevolent leader: Probing the interactions of the dimensions of paternalistic leadership. Asian Journal of Social Psychology, 12(1), 3239.

Northouse, P. G. (1997). Leadership: Theory and practice. Sage publications.

Ortiz, D.C. (2010). "Organizational Commitment \& Its Antecedents: Empirical Evidence from a Developing Country", Southwest Decision Sciences Institute Conference, PA157.

Öner, Z.H. (2012). Servant leadership and paternalistic leadership styles in the Turkish business context: A comparative empirical study. Leadership \& Organization Development Journal, 33(3), 300-316.

Ötken, A. B., \& Cenkci, T. (2012). The impact of paternalistic leadership on ethical climate: The moderating role of trust in leader. Journal of Business Ethics, 108(4), 525-536.

Özkalp, E. \& Kırel, Ç. (2013). Örgütsel Davranış. Bursa: Ekin Basım Yayın Dağıtım.

Pellegrini, E. K., Scandura, T. A., \& Jayaraman, V. (2007). Generalizability of the paternalistic leadership concept: A cross-cultural investigation (working paper). St. Louis: University of Missouri-St. Louis.

Pellegrini, E. K., Scandura, T. A., \& Jayaraman, V. (2010). Cross-cultural generalizability of paternalistic leadership: An expansion of leader-member exchange theory. Group \& Organization Management, 35(4), 391-420.

Pellegrini, E. K., \& Scandura, T. A. (2008). Paternalistic leadership: A review and agenda for future research. Journal of management, 34(3), 566-593.

Randeree, K., \& Ghaffar Chaudhry, A. (2012). Leadership-style, satisfaction and commitment: An exploration in the United Arab Emirates' construction sector. Engineering, Construction and Architectural Management, 19(1), 61-85.

Rehman, M., \& Afsar, B. (2012). The impact of paternalistic leadership on organization commitment and organization citizenship behaviour. Journal of Business Management and Applied Economics, 5(5), 148159. 
Russ, F. A., \& McNeilly, K. M. (1995). Links among satisfaction, commitment, and turnover intentions: The moderating effect of experience, gender, and performance. Journal of Business Research, 34(1), 57-65.

Saher, N., Naz, S., Tasleem, I., Naz, R., \& Kausar, S. (2013). Does paternalistic leadership lead to commitment? Trust in leader as moderator in Pakistani context. Interdisciplinary Journal of Contemporary Research in Business, 5(1), 443-455.

Chan, S. C. (2014). Paternalistic leadership and employee voice: Does information sharing matter?. human relations, 67(6), 667-693.

Tezbaşaran, A. (1997). Likert tipi ölçek geliştirme kılavuzu. Ankara: Türk Psikologları Derneği.

Vandenberg, R. J., \& Lance, C. E. (1992). Examining the causal order of job satisfaction and organizational commitment. Journal of Management, 18(1), 153-167.

Wu, M., Huang, X., \& Chan, S. C. (2012). The influencing mechanisms of paternalistic leadership in Mainland China. Asia Pacific Business Review, 18(4), 631-648.

Wu, M., Huang, X., Li, C., \& Liu, W. (2012). Perceived interactional justice and trust-in-supervisor as mediators for paternalistic leadership. Management and Organization Review, 8(1), 97-121.

Allen, N.J. \& Meyer, J.P. (1996). Affective, continuance and normative commitment to the organization: an examination of construct validity. Journal of vocational behavior, 49, 252-276.

Lok, P. \& Crawford, J. (2003). The effect of organizational culture and leadership style on job satisfaction and organizational commitment. Journal of management development, 23(4), 321-338.

Meyer, J.P. \& Herscovitch, L. (2001). Commitment in the workplace toward a general model. Human resource management review, 11, 299-326. 